University of Nebraska - Lincoln

DigitalCommons@University of Nebraska - Lincoln

Faculty Papers and Publications in Animal

Science

Animal Science Department

1996

\title{
Use of Expected Progeny Differences for Marbling in Beef: I. Production Traits
}

\author{
B. A. Vieselmeyer \\ University of Nebraska-Lincoln \\ Richard J. Rasby \\ University of Nebraska-Lincoln, rrasby1@unl.edu \\ B. L. Gwartney \\ University of Nebraska-Lincoln \\ Chris R. Calkins \\ University of Nebraska-Lincoln, ccalkins1@unl.edu \\ Rick Stock \\ University of Nebraska-Lincoln, rstock3@Unl.edu \\ See next page for additional authors
}

Follow this and additional works at: https://digitalcommons.unl.edu/animalscifacpub

Part of the Animal Sciences Commons

Vieselmeyer, B. A.; Rasby, Richard J.; Gwartney, B. L.; Calkins, Chris R.; Stock, Rick; and Gosey, James A., "Use of Expected Progeny Differences for Marbling in Beef: I. Production Traits" (1996). Faculty Papers and Publications in Animal Science. 589.

https://digitalcommons.unl.edu/animalscifacpub/589

This Article is brought to you for free and open access by the Animal Science Department at DigitalCommons@University of Nebraska - Lincoln. It has been accepted for inclusion in Faculty Papers and Publications in Animal Science by an authorized administrator of DigitalCommons@University of Nebraska - Lincoln. 


\section{Authors}

B. A. Vieselmeyer, Richard J. Rasby, B. L. Gwartney, Chris R. Calkins, Rick Stock, and James A. Gosey 


\title{
Use of Expected Progeny Differences for Marbling in Beef: I. Production Traits ${ }^{1,2}$
}

\author{
B. A. Vieselmeyer, R. J. Rasby3, B. L. Gwartney4, C. R. Calkins, \\ R. A. Stock, and J. A. Gosey
}

Department of Animal Science, University of Nebraska, Lincoln 68583-0908

\begin{abstract}
Six Angus bulls with $\mathrm{HIGH}(>.4)$ and six bulls with LOW $(<-.16)$ expected progeny differences (EPD) for marbling were used to evaluate the impact of marbling on progeny production and carcass traits. Bulls were randomly bred to MARC II ( $1 / 4$ Hereford, $1 / 4$ Simmental, $1 / 4$ Angus, $1 / 4$ Gel bvieh) composite cows in each of $2 \mathrm{yr}$ to calve in the spring. At weaning, steers and heifers were separated and managed in different production systems. Steers ( $\mathrm{n}=$ 131) were fed a growing diet ( $1.1 \mathrm{Mcal}$ of $\mathrm{NE}_{\mathrm{g}} / \mathrm{kg}$ ) for $48 \mathrm{~d}$ followed by adaptation to a $93 \%$ concentrate finishing diet. Heifers $(n=125)$ were fed a growing diet $\left(.79 \mathrm{Mcal}\right.$ of $\mathrm{NE}_{\mathrm{g}} / \mathrm{kg}$ ) for $191 \mathrm{~d}$ followed by
\end{abstract}

adaptation to the same $93 \%$ concentrate diet. Steers and heifers from each treatment were slaughtered at two times spaced about $60 \mathrm{~d}$ apart within both years. Marbling EPD class had no effect on fat thickness, USDA yield grade, carcass weight, finishing daily gain, finishing DMI, or finishing efficiency $(P>.18)$. More $(P<.05)$ carcasses of calves from sires with HIGH EPD for marbling graded USDA Choice than from LOW EPD sires, $74 \%$ vs $47 \%$, respectively. Angus sires can be selected to produce progeny that have increased ability to grade Choice without increasing yield grade or decreasing animal growth or feed efficiency.

\section{Key Words: Beef, Marbling, Expected Progeny Differences}

J. Anim. Sci. 1996. 74:1009-1013

\section{Introduction}

Many U.S. beef breed associations, including the American Angus Association, have carcass EPD available for producers to use as a selection criterion. However, some concern has been raised about the effect of selecting for carcass traits on other production traits, specifically, the relationship of marbling to growth and other carcass traits.

Beef cattle are fed to a level of external fat that provides a reasonable chance for adequate marbling and a desirable dressing percentage. However, the 1991 National Beef Quality Audit (Griffin, 1992; Savell, 1992) determined that excessive fat was reducing the value of beef carcasses up to $\$ 190.00$ each. Previous literature indicates that the genetic correlation of marbling score and fat thickness or live growth traits is low (Koch et al., 1982; Benyshek et al., 1988; Shimada and Willham, 1992; Wilson et al.,

\footnotetext{
${ }^{1}$ Published with the approval of the Director as paper no. 11240, J ournal series, Nebraska Agric. Res. Div.

${ }^{2}$ Funded in part by the Nebraska Beef Council and the American Angus Assoc.

${ }^{3}$ To whom correspondence should be addressed.

4present address: P.O. Box 99, Tar Heel, NC 28392.

Received August 14, 1995.

Accepted J anuary 7, 1996.
}

1993). Marbling score was the carcass grade trait most highly correlated with the palatability attributes (May et al., 1992) and was moderately related to taste panel tenderness $(r=.51)$ and shear force $(r=$ -.61) in Angus $\times$ Hereford steers. Intramuscular marbling, specifically USDA quality grade, is important to the pricing of beef. The objective of this study was to evaluate the impact of EPD for marbling on progeny production and carcass (USDA grade) traits.

\section{Materials and Methods}

Six Angus bulls with high ( HIGH) marbling $(+.4$ to +.83 ) and six with low ( LOW) marbling ( -.16 to -.3) EPD were selected from the 1989 American Angus Association Sire Summary. Each bull selected had an accuracy of at least .42 for marbling. Birth weight and growth EPD accuracies for all bulls were greater than .58. The average EPD for both the high and low marbling sire groups, as taken from the 1989 and 1995 American Angus Association Sire Summaries, are listed in Table 1.

\section{Breeding}

In each of $2 \mathrm{yr}$, approximately 180 MARC II ( $1 / 4$ Hereford, 1/4 Angus, 1/4 Simmental, 1/4 Gelbvieh) cows 
Table 1. Average expected progeny differences for sire group

\begin{tabular}{|c|c|c|c|c|c|c|c|}
\hline $\begin{array}{l}\text { Sire Summary } \\
\text { year and } \\
\text { sire group }\end{array}$ & $\begin{array}{l}\text { No. of } \\
\text { of bulls }\end{array}$ & $\begin{array}{l}\text { Average } \\
\text { EPD for } \\
\text { birth wt }\end{array}$ & $\begin{array}{c}\text { Average } \\
\text { EPD for } \\
\text { weaning wt }\end{array}$ & $\begin{array}{c}\text { Average } \\
\text { EPD for } \\
\text { yearling wt }\end{array}$ & $\begin{array}{l}\text { Average } \\
\text { EPD for } \\
\text { ribeye }^{b}\end{array}$ & $\begin{array}{l}\text { Average } \\
\text { EPD for fat } \\
\text { thickness }\end{array}$ & $\begin{array}{l}\text { Average } \\
\text { EPD for } \\
\text { marbling }\end{array}$ \\
\hline \multicolumn{8}{|l|}{$1989^{d}$} \\
\hline High & 6 & +5.2 & +21.5 & +41.1 & -.11 & +.01 & +.59 \\
\hline Low & 6 & +6.1 & +27.0 & +51.6 & +.14 & -.02 & -.23 \\
\hline \multicolumn{8}{|l|}{$1995^{\mathrm{e}}$} \\
\hline High & 6 & +4.0 & +25.0 & +39.7 & +.13 & -.03 & +.33 \\
\hline Low & 6 & +5.1 & +28.5 & +50.0 & +.17 & +.00 & -.35 \\
\hline
\end{tabular}

${ }^{a} E P D$ in pounds.

bEPD in square inches.

CEPD in inches.

dTaken from the 1989 American Angus Association Sire Summary.

'Taken from the 1995 American Angus Association Sire Summary.

and heifers at the Dalbey-Halleck Farm (Virginia, NE ) were bred to the selected Angus bulls by artificial insemination. The breeding order of the bulls was randomized for each breeding season and breeding location. Females were therefore mated randomly to 1 of the 12 bulls over a 42-d breeding season. Cows or heifers that exhibited estrus after the first breeding were bred to the same bull used during the first service.

\section{Calving to Weaning}

Calves were born between February 19 and April 24, 1990, and between February 27 and April 18, 1991. Calving difficulty scores were recorded using a 1 to 5 scoring system (Table 2). Calves were tagged and tattooed and bulls castrated at birth. All calves received calfhood vaccinations prior to grazing summer pasture with their dams. Steer and heifer calves were weaned both years on October 15.

\section{Growing and Finishing}

Weaning weight of steers was the average of weights taken at the farm and feedlot. Both years on weaning day, steers were weighed at the farm then transported to the Agricultural Research and Development Center feedlot (Mead, NE) where they were weighed and then penned according to sire group. A receiving diet ( $1.1 \mathrm{Mcal}$ of $\mathrm{NE}_{\mathrm{g}} / \mathrm{kg}$ ) was fed for $30 \mathrm{~d}$ and a growing diet ( $1.1 \mathrm{Mcal}$ of $\mathrm{NE}_{\mathrm{g}} / \mathrm{kg}$ ) was fed for 16 and $19 \mathrm{~d}$ for $\mathrm{yr} 1$ and 2, respectively. The initial weight for the finishing period was the average of weights taken on two consecutive days' feeding at the end of the growing period. Steers were implanted with $24 \mathrm{mg}$ of Compudose ${ }^{\circledR}$ (Elanco Animal Health, Indianapolis, IN) at the start of the finishing period. Steers were then adjusted to the finishing diet in $21 \mathrm{~d}$ using three adaptation diets containing 35, 25 and $15 \%$ (DM basis) forage (corn silage and alfalfa hay assumed to equal 50 and $100 \%$ forage, respectively). Each diet was fed for $7 \mathrm{~d}$. The final diet contained
$7.5 \%$ roughage and $1.36 \mathrm{Mcal}$ of $\mathrm{NE}_{\mathrm{g}} / \mathrm{kg}$ and was formulated for $12 \%$ crude protein, .7\% calcium, .35\% phosphorus, .7\% potassium, $28 \mathrm{mg} / \mathrm{kg}$ Rumensin (Elanco Animal Health), and $11 \mathrm{mg} / \mathrm{kg}$ Tylan (Elanco Animal Health) (DM basis).

Weaning weight of the heifers was an average of weights taken two consecutive days before feeding. Heifers, after weaning, were fed a diet that consisted (as-fed basis) of .7 kg of a $32 \%$ protein supplement, $2.3 \mathrm{~kg}$ of corn, prairie hay ad libitum, and a free-choice vitamin and mineral supplement for $191 \mathrm{~d}$ both years. Age at puberty data were collected and reported by Bergfeld et al. (1995). On April 24 and 23, for yr 1 and 2, respectively, heifers were transported to the Agricultural Research and Development Center feedlot where they were allotted to pens by sire group, implanted with $24 \mathrm{mg}$ of Compudose, and fed adaptation diets containing 50, 35, 25, and $15 \%$ (DM basis) forage for $7 \mathrm{~d}$ each. Initial finishing weight was the average of a weight taken at the farm prior to trucking and a weight upon arrival at the feedlot. The heifers were fed the same finishing diet as the steers.

Steers were fed separately in four pens each year, two pens of each marbling treatment, with all sires within a marbling treatment represented in both pens. Heifers were allocated to pens and fed the same as the steers.

\section{Slaughter}

Both steers and heifers were slaughtered at two mean fat thickness end points estimated visually to be .64 and $1.27 \mathrm{~cm}$ at the 12th rib. One pen of steers representing each marbling treatment was slaughtered after 126 and $196 \mathrm{~d}$ of feeding for $\mathrm{yr} 1$ and 122 and $185 \mathrm{~d}$ of feeding for $\mathrm{yr} 2$. The heifers were slaughtered after 85 and $148 \mathrm{~d}$ of feeding in yr 1 and 84 and $147 \mathrm{~d}$ of feeding in yr 2. Days on feed does not include the growing period. Yield grade and quality grade information was collected for both steers and heifers after a 72-h chill. Final weights were calculated from carcass weights assuming a 62 dressing percentage. 
Table 2. Production traits of steers and heifers sired by low or high marbling expected progeny difference sires

\begin{tabular}{|c|c|c|c|c|c|}
\hline \multirow[b]{2}{*}{ Item } & \multicolumn{2}{|c|}{ Steer system ${ }^{a b}$} & \multicolumn{3}{|c|}{ Heifer system ${ }^{c}$} \\
\hline & Low & High & Low & High & SEM \\
\hline No. of animals & 63 & 66 & 65 & 59 & - \\
\hline $\begin{array}{l}\text { Suckling } \\
\text { Birth wt, } \mathrm{kg}^{\mathrm{d}} \\
\text { Calving difficulty } \\
\text { Adjusted 205-d wt, kgdf } \\
\text { Actual weaning wt, kgdf }\end{array}$ & $\begin{array}{c}42 \\
1.5 \\
245 \\
240\end{array}$ & $\begin{array}{c}43 \\
1.4 \\
238 \\
229\end{array}$ & $\begin{array}{c}39 \\
1.3 \\
234 \\
230\end{array}$ & $\begin{array}{c}39 \\
1.5 \\
223 \\
215\end{array}$ & $\begin{array}{r}.41 \\
.07 \\
1.53 \\
2.03\end{array}$ \\
\hline $\begin{array}{l}\text { Finishing } \\
\text { Initial wt, kg df } \\
\text { Final wt, kg } \\
\text { Daily gain, kg } \\
\text { Feed intake, kg/d } \\
\text { Feed/gaindg }\end{array}$ & $\begin{array}{r}290 \\
550 \\
1.33 \\
8.64 \\
6.47\end{array}$ & $\begin{array}{r}278 \\
497 \\
1.39 \\
8.83 \\
6.36\end{array}$ & $\begin{array}{r}335 \\
503 \\
1.43 \\
11.05 \\
7.75\end{array}$ & $\begin{array}{l}321 \\
484 \\
1.39 \\
10.4 \\
7.47\end{array}$ & $\begin{array}{r}3.17 \\
5.66 \\
.03 \\
.19 \\
.23\end{array}$ \\
\hline $\begin{array}{l}\text { Carcass } \\
\text { \% Choice } \\
\text { Yield grade } \\
\% \text { YG1 } \\
\% \text { YG2 } \\
\% \text { YG3 } \\
\% \text { YG4 }\end{array}$ & $\begin{array}{l}47 \\
2.82 \\
4.7 \\
60.3 \\
28.7 \\
6.3\end{array}$ & $\begin{array}{l}77 \\
2.90 \\
4.5 \\
57.6 \\
31.8 \\
6.1\end{array}$ & $\begin{array}{l}47 \\
2.52 \\
16.9 \\
72.3 \\
9.3 \\
1.5\end{array}$ & $\begin{array}{l}72 \\
2.47 \\
16.9 \\
62.8 \\
18.6 \\
1.7\end{array}$ & $\begin{array}{l}.2 \\
.05 \\
.35 \\
.35 \\
.35 \\
.35\end{array}$ \\
\hline
\end{tabular}

aSex $\times$ marbling for all measurements $(P>.1)$, thus data were pooled across sex.

bsteer system: 46- or 49-d growing period followed by finishing.

CHeifer system: 191-d growing period followed by finishing.

dsex effect $(\mathrm{P}<.01)$.

$\mathrm{e}_{1}=$ no assistance, 2 =minor difficulty, 3 =mechanical assistance, 4 =Caesarean section, 5 =abnormal presentation.

$\left.f_{\text {Marbling effect }(} P<.01\right)$.

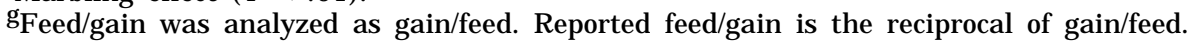

\section{Statistical Analysis}

Statistical analysis was conducted using the GLM procedure of SAS (1989). For birth and weaning data, individual animal was the experimental unit; finishing pen was the experimental unit for finishing and carcass measurements. All possible two- and threeway interactions of all independent variables (treatment, slaughter time, sex, and year) were tested and no interactions were significant $(P>.1)$. The percentage USDA Choice and yield grade were tested using the CATMOD procedure of SAS (1989). All interactions were tested and none was significant $(P>.1)$. The outcome of this analysis is only applicable to the population of Angus sires used in this study.

\section{Results and Discussion}

\section{Calving and Weaning}

Steers weighed $3 \mathrm{~kg}$ more $(P<.01)$ at birth than heifers (Table 2). No effect of sire group from either LOW or HIGH marbling sires was observed on either calving weight or degree of dystocia. Actual weaning weights of calves sired by LOW marbling bulls were 11 and $15 \mathrm{~kg}$ heavier $(P<.01)$ for steers and heifers, respectively, than weaning weights of calves sired by HIGH marbling sires. This difference was also reflected when weaning weights were adjusted to 205-d weaning weights according to BIF (1990). Steers and heifers sired by LOW marbling bulls weighed 7 and $11 \mathrm{~kg}$ greater, respectively, than steers and heifers from HIGH marbling bulls, after adjustment.

Selection for the test bulls was by marbling EPD only. Differences in weight at weaning are probably due to the higher growth EPD of the LOW sires (Table 1), even though observed differences in weaning weights exceeded the differences in weaning weight EPD.

\section{Growing and Finishing}

Marbling treatment did not affect $(P>.01)$ the growing gains of the heifers, .56 kg/d (Bergfeld et al., 1995), or steers, $1.06 \mathrm{~kg} / \mathrm{d}$. Finishing dry matter intake and feed/gain were higher $(P<.01)$ for the heifers than for the steers (Table 2 ) due to the different management system and older age of the heifers. Because no sex $\times$ marbling treatment interactions were observed for finishing and carcass traits, steer and heifer data were pooled. Daily gain, dry matter intake, and feed efficiency during finishing, averaged across both slaughter times, were not different for progeny sired by HIGH or LOW marbling EPD sires (Table 2). Final weights were similar ( $P>$ 
Table 3. Carcass traits of progeny sired by low or high marbling expected progeny difference sires at the two slaughter times over both years

\begin{tabular}{|c|c|c|c|c|c|}
\hline \multirow[b]{2}{*}{ Item } & \multicolumn{2}{|c|}{ Slaughter \#1 } & \multicolumn{3}{|c|}{ Slaughter \#2 } \\
\hline & Low & High & Low & High & SEM \\
\hline No. of animals & 64 & 60 & 64 & 65 & \\
\hline Fat, $\mathrm{cm}$ & .88 & .84 & 1.31 & 1.31 & .05 \\
\hline Carcass wt, kg & 280 & 273 & 341 & 334 & 6.33 \\
\hline$\%$ Choice $^{\mathrm{a}}$ & 17 & 52 & 78 & 96 & .2 \\
\hline Yield grade & 2.4 & 2.4 & 2.9 & 3.0 & .13 \\
\hline Longissimus muscle area, $\mathrm{cm}^{2}$ & 74.19 & 72.9 & 84.52 & 81.94 & 2.06 \\
\hline
\end{tabular}

aMarbling effect $(P<.01)$.

.18) between the LOW and HIGH treatments at slaughter, contrary to the weight difference observed at weaning.

Although there were no gain or final weight differences between HIGH and LOW marbling EPD sires in this experiment, the genetic relationships between carcass composition and growth have been observed by others. Arnold et al. (1991) observed that the highest genetic correlations for marbling were with relative growth rate and total daily gain from weaning to slaughter. Fitzhugh and Taylor (1971) described average relative growth rate as a measure of maturation rate. Arnold et al. (1991) inferred that animals that mature more quickly might deposit marbling at a higher rate than those that mature more slowly.

Other research indicates that selection for larger frame size and higher rate of growth would have a negative effect on marbling. Koch (1978) indicated that selection in Hereford heifers for weaning or yearling weight would lead to a slight decline in marbling, yet this could be overcome by using carcass evaluations in progeny or sibling tests. Estimates from the age-constant analysis of Cundiff et al. (1971) indicated that marbling has a low genetic association with growth of retail product and bone in the carcass but has a high positive correlation with rate of fat deposition. Therefore, they concluded that selection for estimated cutability would be effective in improving actual proportion of retail product; however, such selection clearly would lead to reduced marbling and carcass quality grade. However, more recent research indicated that cattle can be selected for growth or increased retail product and reduced external fat without sacrificing marbling traits (Shimada and Willham, 1992; Woodward et al., 1992; Wilson et al., 1993).

\section{Carcass}

Substantially more steers and heifers in the HIGH marbling group graded USDA Choice (Table 2 ) than those in the LOW marbling group $(P<.01)$. More than $70 \%$ of the progeny from HIGH marbling bulls graded Choice compared to less than $50 \%$ of the LOW marbling sired progeny. This difference is greater for the first slaughter time; $52 \%$ of the cattle in the $\mathrm{HIGH}$ marbling group as opposed to $17 \%$ of the cattle in the LOW group graded Choice. Steers and heifers that had sufficient marbling to grade Choice at the second slaughter time were $96 \%$ and $78 \%$ for the HIGH and LOW treatments, respectively. Bertrand et al. (1993) suggested that a threshold number of days was necessary for genetic differences for marbling to be manifested from steers from sires with high marbling EPD compared to steers from randomly selected bulls, but this was not evident in this experiment.

The percentage Choice differences between progeny of LOW and HIGH marbling sires were larger than anticipated from the marbling EPD of the sires. The heritability for marbling score used by the American Angus Association Carcass Evaluation is currently .31 (Wilson, 1994). Heritability estimates for marbling range from .23 to .47 (Cundiff et al., 1969, 1971; Koch, 1978; Wilson and Rouse, 1987; Arnold et al., 1991; Woodward et al., 1992; Wilson et al., 1993).

Subcutaneous fat measured at the 12th rib was not different $(P>.6)$ for marbling treatment (Table 3 ). Wilson et al. (1993), using the carcass data set from the American Angus Association that included data from 1974 to 1992, reported the genetic correlation between fat thickness and marbling at -.13. This is consistent with other studies, including that of Benyshek et al. (1988), who reported an estimate of .08 , and that of Koch et al. (1982), who reported an estimate of .16. These data and the results from the present study clearly indicate that it is possible to use available genetics to select for cattle with increased marbling at the same fat thickness.

Longissimus area (Table 3 ) did not differ for marbling group (data not shown) but heifers did have larger longissimus muscle areas than the steers $(\mathrm{P}<$ $.01)$, which was due to the management system. There was no difference $(P>.1)$ in the percentage of cattle from either marbling group within each USDA yield grade (Tables 2 and 3 ).

The production performance of cattle in non-carcass traits may be influenced if producers select strictly on carcass EPD. Woodward et al. (1992) concluded that the lower additive genetic variance estimates for 
carcass traits, in comparison to growth traits, suggest that slow genetic progress in carcass traits would result if major emphasis were put on carcass traits in a selection program. Others (Cundiff et al., 1964; Dinkel and Busch, 1973; Wilson et al., 1976; Koch, 1978) also have determined that selection emphasis placed on growth traits is more effective than selection on carcass traits.

Selection for any singular trait in beef cattle is sure to influence other traits of economic importance in a beef herd. In this particular study, the weight differences at weaning were a reflection of the weaning weight EPD of the sires. Progeny whose sires differed in marbling EPD did not result in differences in finishing growth or feed efficiency in this experiment.

\section{Implications}

This experiment indicates that Angus sires can be selected to produce progeny that have increased ability to marble without increasing subcutaneous fat. This would enable cattle to grade Choice with less time on feed and potentially reduce the amount of external fat produced and subsequently trimmed from the carcass or retail cuts if the industry continues toward the trend of closely trimmed cuts. The current beef producer-packer marketing system is primarily based on weight, which encourages the production of heavier, fatter carcasses. A value-based marketing system with a premium for lean but marbled beef would allow the genetic potential of carcass merit to be reflected in economic terms.

\section{Literature Cited}

Arnold, J. W., J . K. Bertrand, L. L. Benyshek, and C. Ludwig. 1991. Estimates of genetic parameters for live animal ultrasound, actual carcass data, and growth traits in beef cattle. J. Anim. Sci. 69:985.

Beef Improvement Federation. 1990. Guidelines for Uniform Beef Improvement Programs (6th Ed.). Oklahoma State Univ., Stillwater.

Benyshek, L. L., J . W. Comerford, D. E. Little, and C. Ludwig. 1988. Estimates of carcass trait genetic parameters from Hereford field data. J. Anim. Sci. 66(Suppl. 1):10 (Abstr.).

Bergfeld, E. G., R. J . Rasby, M. K. Nielsen, and J . E. Kinder. 1995. Heifers sired by bulls with either high or low expected progeny differences (EPD) for marbling do not differ in age at puberty. Anim. Reprod. Sci. 40:253.
Bertrand, J . K., W. O. Herring, S. E. Williams, and L. L. Benyshek. 1993. Selection for increased marbling and decreased backfat in Angus cattle using expected progeny differences. J . Anim. Sci. 71(Suppl. 1):93 (Abstr.).

Cundiff, L. V., D. Chambers, D. F. Stephens, and R. L. Willham. 1964. Genetic analysis of some growth and carcass traits in beef cattle. J . Anim. Sci. 23:1133.

Cundiff, L. V., K. E. Gregory, R. M. Koch, and G. E. Dickerson. 1969. Genetic variation in total and differential growth of carcass components in beef cattle. J. Anim. Sci. 29:233.

Cundiff, L. V., K. E. Gregory, R. M. Koch, and G. E. Dickerson. 1971. Genetic relationships among growth and carcass traits of beef cattle. J. Anim. Sci. 33:550.

Dinkel, C. A., and D. A. Busch. 1973. Genetic parameters among production, carcass composition and carcass quality traits of beef cattle. J. Anim. Sci. 36:832.

Fitzhugh, H. A., J r., and St. C. S. Taylor. 1971. Genetic analysis of degree of maturity. J. Anim. Sci. 33:717.

Griffin, D. B. 1992. Excessive seam fat in primals and subprimals; excess fat in beef trimmings. In: G. C. Smith ( $\mathrm{Ed}$.) The Final Report of the National Beef Quality Audit-1991. Colorado State Univ., Fort Collins and Texas A\&M Univ., College Station.

Koch, R. M. 1978. Selection in beef cattle III. Correlated response of carcass traits to selection for weaning weight, yearling weight and muscling score in cattle. J. Anim. Sci. 47:142.

Koch, R. M., L. V. Cundiff, and K. E. Gregory. 1982. Heritabilities and genetic, environmental and phenotypic correlations of carcass traits in a population of diverse biological types and their implications in selection programs. J. Anim. Sci. 55:1319.

May, S. G., H. G. Dolezal, D. R. Gill, F. K. Ray, and D. S. Buchanan. 1992. Effects of days fed, carcass grade traits, and subcutaneous fat removal on postmortem muscle characteristics and beef palatability. J . Anim. Sci. 70:444.

SAS. 1989. SAS User's Guide: Statistics. SAS Inst. Inc., Cary, NC.

Savell, J. W. 1992. Low yield grades-excessive external fat. In: G. C. Smith (Ed.) The Final Report of the National Beef Quality Audit-1991. Colorado State Univ., Fort Collins and Texas A\&M Univ., College Station.

Shimada, K., and R. L. Willham. 1992. Genetic parameters for growth and carcass traits in three size lines of beef cattle. pp 1-4. A.S. Leaflet R892. Cooperative Extension Service, Iowa State Univ., Ames.

Wilson, D. E. 1994. Angus Carcass Evaluation. In: American Angus Association Sire Evaluation Report-Fall 1994. American Angus Association, St. J oseph, MO.

Wilson, D. E., R. L. Willham, S. L. Northcutt, and G. H. Rouse. 1993. Genetic parameters for carcass traits estimated from Angus field records. J. Anim. Sci. 71:2365.

Wilson, D. E., and G. H. Rouse. 1987. Genetic evaluation of Angus sires for carcass traits. pp 27-32. A.S. Leaflet R437. Cooperative Extension Service, lowa State Univ., Ames.

Wilson, L. L., J . R. McCurley, J . H. Ziegler, and J . L. Watkins. 1976. Genetic parameters of live and carcass characters from progeny of Polled Hereford sires and Angus-Holstein cows. J . Anim. Sci. 43:569.

Woodward, B. W., E. J . Pollak, and R. L. Quaas. 1992. Parameter estimation for carcass traits including growth information of Simmental beef cattle using restricted maximum likelihood with a multiple-trait model. J. Anim. Sci. 70:1098. 